\title{
The Organization of Insurance Companies: Mutual versus Stock
}

\author{
HENRY HANSMANN \\ Yale University
}

\section{INTRODUCTION}

For the student of industrial organization, the insurance industry presents a number of interesting problems. One of the most interesting, and least studied, concerns the degree to which the insurance industry is populated with mutual rather than investor-owned firms.

Mutuals account for almost half of all life insurance in force and one quarter of all property and liability insurance. There are few other industries in which consumer cooperatives-of which mutuals are an example-account for such a large share of the market. In fact, the annual volume of business done by mutual life insurance companies far outweighs the volume of business done by consumer cooperatives in any other line of business. And it is not just in comparison with other cooperatives that the mutual insurance companies appear large; the assets of the largest of the mutuals, Prudential, exceed those of any industrial corporation (Fortune, 1983a: 228; 1983b: 166). At present, however, we have no well-accepted theory to explain the remarkable prominence of the cooperative form in this industry. Indeed, the subject has hardly been discussed.'

In this article I seek to offer an explanation. The question is of interest not just as a matter of positive economics, but also for law and public policy. The

I wish to thank Reinier Kraakman for useful discussions, and the participants in the Yale Law School Conference on Law, Economics, and Organization for helpful comments on an earlier draft.

1. There are brief treatments of the general topic in May'ers and Snith (425-28) and in Fama and Jensen $(337-41)$, while Heflebower (chap. 12) devotes a chapter to property and liability mutuals. The partial theories offered by these authors are discussed in footnotes below.

Journal of Laue, Economics, and Organization vol. 1, no. 1 Fall 1985

(C) 1985 by Yale University. All rights reserved. ISSN 8756-6222 
organizational, regulatory, and tax law to which insurance companies are subject has an influence on the choice of form and has often been selfconsciously structured with this influence in mind-either to encourage one form or another or to maintain neutrality between them. For example, some of the largest mutual life insurance companies were originally formed as stock companies but converted to the mutual form early in this century, partly in response to pressure put upon them by state regulatory authorities. ${ }^{2}$ The taxation of life insurance companies underwent major reform in 1959, and again in 1984, primarily for the purpose of avoiding inappropriate discrimination between mutual and stock companies. And today there is considerable interest among the mutuals in converting to the stock form (Dannen), which raises important questions as to whether and how such conversions should be permitted under the law.

\section{THE COOPERATIVE FORM}

In general, firms are organized as consumer cooperatives only where two broad conditions are satisfied: (1) there is relatively severe market failure ${ }^{3}$ in the firm's product market, and (2) consumers are able to assume effective control without incurring excessive costs. Absent one or both of these conditions, the conventional investor-owned firm is generally dominant-and hence, we can reasonably conclude, a more efficient form of organization.

\subsection{Market Failure}

Although other forms of market failure are sometimes involved, consumer cooperatives most typically arise where the firm in question is in a postion of natural monopoly or otherwise faces very limited competition (Hansmann, 1980: 889-94; Heflebower: 10-12, 25-31). The obvious advantage of the consumer cooperative in such a situation is that it substitutes an ownership relationship for the imperfect market, thus eliminating the conflict of interest between the firm's owners and consumers and providing some assurance to the consumer/owners that the firm will not charge them monopoly prices.

\subsection{The Cost of Consumer Control}

Market failure is, however, only a necessary, and not a sufficient, condition for the survival of consumer cooperatives in a competitive market. In ad-

2. See section 3.6 below:

3. I am sensitive to the vagueness of the term market failure. What we are concerned with here is, most generally, a search for the least-cost solution to a contracting problem; markets of a traditional trpe are only one among many possible solutions. The term market failure is used here simply to refer to some of the most familiar conditions under which market solutions involve relatively large costs for those involved. 
dition, circumstances must be such that the costs of establishing effective consumer control (as opposed to control by investors) are modest in relation to the gains that derive from mitigating the effects of market failure in the product market. Generally this means that consumer cooperatives arise in situations in which the consumers involved find it convenient to purchase goods or services repeatedly from the same firm over a substantial period of time, and the value of the purchases is relatively large; otherwise the transaction costs of registering, keeping track of, and communicating with members will be disproportionate to the value of goods consumed. It also means that consumer cooperatives are typically small--to keep within bounds the consumer/members' incentive to free-ride on the monitoring efforts of other consumers-and serve primarily consumers who reside near the cooperative, so that they can personally monitor the operations of the firm.

Relatively small requirements for organization-specific capital are also important to the success of the cooperative form. Where large amounts of organization-specific capital are involved, debt financing will be expensive. Yet equity capital must come from the cooperative's consumer/members', which raises several problems. First, the advantage of diversifying risk through the equity markets is lost. Second, the difficulty of imputing the proper implicit return to capital is likely to lead to shifts of wealth among classes of consumers, either currently or over time. Third, it will be difficult to return capital investments to consumers who wish to withdraw their patronage from the firm. And fourth, the transaction costs of collecting the capital necessary to establish a cooperative in the first place may be high. ${ }^{+}$

4. Fama and Jensen (336-41) also argue that financial mutuals are most likely to appear in industries that require relatively small amounts of organization-specific assets. They base this conclusion, however, on different grounds than those emphasized here. Their argument is that small amounts of organization-specific assets make it relatively easy to permit consumer/mem. bers to exit from the firm by withdrawing their patronage and their capital contribution. The partial liquidation involved in such a withdrawal is, they suggest, a means of sanctioning the managers of the firms, and thus makes up to some extent for the fact that such firms are not subject to the discipline afforded by the market for corporate control that characterizes investorowned corporations. Indeed, Fama and Jensen state that "the unique characteristic of the residual claims of mutuals, which is important in understanding their survival value, is that the residual claims are redeemable on demand" (338), and they focus their entire discussion of financial mutuals on this presumed characteristic.

Full redeemability of claims has not, however, been a characteristic of mutuals in the life insurance industry, which is the industry in which financial mutuals play the largest role by far. Indeed, in the early years of the life insurance industry, when mutuals were at their historical high in terms of market share (the period 1843-59-see section 3.6 below) policyholders had no right at all to redeem their life insurance policies for cash or even to borrow against them; rather, a policyholder had only the options of paying premiums at the contracted rate throughout the term of his policy (i.e., until his death in the case of a whole life policy) or of forfeiting ' the company the full accumulated value of his policy (Stalson: 315-25). Furthermore, for reaso. we shall discuss below in section 3.6, even today life insurance policies generally have cash surrender values substantially smaller than the accumulated value of the premium payments that have been made on them (McGill: 61). 
Finally, it is evidently important that consumers in a cooperative all purchase goods or services that are similar in type and quantity. Otherwise, there is room for difference in objectives among the consumer/members, and this can lead either to exploitation of one group of members by another or to strategic behavior that will increase considerably the costs of decisionmaking within the firm.

\subsection{Comparison with Nonprofit Firms}

Nonprofit firms, like cooperatives, also generally arise where there is serious market failure in the product market. But where nonprofits are concerned, the type of market failure typically involved is not simple monopoly, but rather what I have elsewhere termed "contract failure." Contract failure is essentially a problem of asymmetric information; it involves situations in which consumers are for one reason or another unable to monitor adequately the quantity or quality of goods or services that a firm produces for them. Corresponding to this difference in the types of market failure to which consumer cooperatives and nonprofits typically respond is a difference in the types of products that are commonly produced by the two types of firms. Cooperatives generally supply simple, easily evaluated products and commodities such as groceries, hardware, and books (Heflebower: 4), while nonprofits generally supply complex services such as nursing care, day care, and education. Moreover, nonprofits commonly-though not always-arise where the costs of establishing effective consumer control are relatively high (Hansmann, 1980: 890-94).

\subsection{Do Insurance Companies Fit?}

It is not obvious, at first glance, that insurance companies meet the market failure and cost-of-consumer-control conditions that usually characterize consumer cooperatives. To begin with, market concentration seems relatively low in the insurance industry. Hundreds of companies sell life insurance, and, although four-firm concentration ratios of between 20 and 40 percent are relatively common among the various lines of property and liability insurance, there are few lines that exhibit higher degrees of market concentration than this (Best's Aggregates and Averages, Property-Liability: 110-31, 186-200). Furthermore, effective consumer control seems often to be completely absent in the mutuals. A given mutual's policyholder/owners often number in the tens of thousands and are spread all over the country, and the shareholder proxy machinery that federal law mandates for publicly held business corporations does not apply to mutual insurance companies. Consequently, management in many mutual insurance companies is commonly self-appointing and free of any supervision or control by members whatsoever (Hetherington). 
Upon closer inspection, however, it appears that the insurance industry satisfies reasonably well the general characteristics that typify other industries in which consumer cooperatives are common. Market failure is still of central importance, though it appears in somewhat uncommon forms in the insurance industry. And the cost-of-consumer-control factors evidently also play a central role.

\section{LIFE INSURANCE}

Three related factors combine to make market competition alone an insufficient source of discipline for proprietary firms marketing life insurance and consequently create - or at least created in the early years of the life insurance industry -an incentive for adoption of the mutual form: (1) the difficulty of writing an adequate long-term contract between the insurance company and the policyholder in the face of substantial uncertainty; (2) asymmetry of information between policyholders and insurance companies concerning important aspects of the company's performance; and (3) the need to lock policyholders into a company in order to avoid problems of adverse selection.

\subsection{Long-Term Contracting under UNCERTAinty}

A life insurance policy is a long-term contract between the insurance company and the insured that typically has a duration of several decades and often is in force for more than half a century. In such a long period of time, many contingencies can arise that can affect the value of the bargain to one or both parties. Writing an enforceable contract that will anticipate and deal with such contingencies adequately is a difficult task. Because the contract is for insurance, it is obviously important that the contract deal effectively with contingencies in a way that imposes minimal risks on the insured. The central problem in this respect lies in making provision for the insurance company to maintain financial reserves that are adequate to pay off its policies when claims against them are filed.

Consider, for example, the simple case of an insurance company that sells whole life insurance, financed by level premiums, at a single time to a single cohort of 10,000 thirty-five-year-olds. Each policy, let us assume, provides for $\$ 100,000$ in insurance, so that the company initially has one billion dollars of insurance in force. Finally, let us suppose that the life expectancy for this cohort, based on the best current statistics, is seventy-five years, although this projection is subject to some uncertainty.

If the insurance company is risk-neutral, it should be willing to sell policies on terms such that the present value of the expected premium stream equals the present value of a $\$ 100,000$ payment to be made forty years in the future, plus any transaction costs of administering the company. If the busi- 
ness is competitive, this is in fact the price at which we should expect the policies to sell. How much invested capital should the company then maintain? Suppose that it raises no capital through either debt or equity financing but simply accumulates premium payments to establish the reserve out of which claims are to be paid. Then, if mortality turns out to be higher than was expected at the time the policies were sold-that is, if the estimated life expectancy of seventy-five years turns out to be an overestimate-the company will have insufficient reserves with which to pay its claims, and it will have to default on some fraction of its policies. Indeed, if the estimate of life expectancy at the time the policies are sold has a normal distribution, then there is a 50 percent probability that a company following such a policy will find itself with insufficient reserves with which to pay off its claims. Such a level of risk is presumably much too high to be attractive to the typical purchaser of life insurance.

There are two obvious ways to avoid this problem. The first is to charge a premium such that the expected value of the stream of premium payments is considerably in excess of the company's expected liability on the policy, so that the reserves established by accumulating and investing the premium payments at all times exceeds by a comfortable margin even a pessimistic estimate of the company's potential liability on its policies. This approach, however, makes the expected cost of a policy to the insured considerably higher than its expected value and promises the company's owners substantial pure profits. The second approach, and the one that is most efficient, is for the owners of the insurance company to invest equity capital in the company in an amount such that, when added to the accumulated policy premiums at any given time, it provides a sufficient reserve to pay off all claims even when mortality turns out to be higher than expected.

How much invested capital is then appropriate? The most conservative policy would be to maintain reserves at all times equal to the total amount of insurance that the company has in force. In the case of our example, this would call for initial invested capital of roughly one billion dollars-enough to pay off on all policies if a plague were to strike down all of the company's 10,000 policyholders before their thirty-sixth birthdays. As premiums were paid in subsequent years, and as investment income was earned on the company's investments, distributions could then be made to shareholders annually in amounts just sufficient to maintain equality between total assets and total insurance in force. Presumably such a reserve requirement could be put in insurance contracts without too much difficulty: the company would simply promise to each policyholder, as part of the contract of insurance, that the company would never sell an insurance policy now or in the future if it would result in the company having insurance in force greater than the value of the company's liquid assets.

But such a policy would undoubtedly be too conservative; tying up so 
much capital as security for claims against policies would impose costs on shareholders (and hence, through higher premiums, on policyholders) in excess of the value of the security it would provide to policyholders. Reserves equal simply to some fraction of total insurance in force should generally be adequate. But what fraction? Even in the simple case of our single cohort of thirty-five-year-olds it would require sophisticated actuarial and financial calculations to determine an appropriate figure. Moreover, the appropriate fraction would increase as the cohort of insureds grew older. Thus, a contract specifying the amount of reserves the company must maintain at any time would have to embody an elaborate table or formula. And, as we move to more realistic examples in which the company insures not simply a single cohort of people of the same age, but rather a group of individuals of diverse ages, and with different life expectancies owing to apparent differences in health, heredity, and occupation, the complexity of the tables or formulas would increase by new orders of magnitude. An individual comparing the policies offered by two different companies would not simply be able to look at the respective premium levels. Nor would it be sufficient to go further and discover the current ratio of reserves to insurance in force for the two firms, or to assess in addition the age and risk distribution of the respective companies' policyholders. Rather, the companies' formulas for establishing required reserves would have to be compared in detail.

But the complexity does not end here. So far we have ignored all risks other than the simple risk that the mortality of a company's policyholders will turn out to be higher than its expected value at the time that the company's policies were written. In addition, however, there are the risks that the return on the company's investment will be lower than was expected when the policies were written or (assuming that, as is usual, the policies are written in terms of nominal dollars) that the long-run inflation rate will turn out to be lower than the company predicted. The required level of reserves may need to be increased to cover these risks. Or, alternatively, the company may need to promise in its contracts of insurance that it will raise new capital-by selling either equity or debt subordinated to policy claims-in case unusually low inflation or return on investments should ever bring reserves below the required ratio to insurance in force. And of course policies would also have to specify the risk level of the investments that the company could make with its reserves; otherwise, since the downside risk to the company is limited by bankruptcy, the company would have an incentive to behave opportunistically by investing in highly speculative assets to increase the expected return to its shareholders.

It seems, then, that if we were to rely completely upon private contracting to police insurance markets, an adequate contract of insurance would need to be a very complex thing. 


\subsection{ASYMMETRIC INFORMATION}

An adequate contract of insurance would be difficult to design even if the insurance company and the policyholders were extremely sophisticated about the financial and actuarial factors involved. In fact, however, the available evidence suggests that policyholders are, by and large, relatively uninformed. For example, prices vary widely for equivalent policies (Belth, 1966, 1969; Geehan). Consequently, contracting takes place here in an environment of asymmetric information (which is not to say that we should have a high estimate of the sophistication of the firms involved, either). ${ }^{5}$ There is therefore every reason to expect that unregulated private contracting between insurance firms and their customers will not result in optimal contracts. Consumers will be unable to distinguish between life insurance policies of widely varying soundness, with the result that an inefficient "lemons" market can be expected (Akerloff).

\subsection{Adverse SELECTION AND LOCK-IN}

Poor information is not the only factor handicapping consumers in looking out for their interests when dealing with life insurance companies. Another problem is that premium payments on life insurance policies are typically designed - and indeed must be designed-to make it very expensive for a policyholder to switch to another company if at some point he becomes dissatisfied with the behavior of the company from which he originally purchased a policy.

If premium payments on life insurance policies were designed so that each year's payment just covered the cost to the company of insuring the policyholder's life for the year in which the payment was made, the company would experience serious problems of adverse selection. By the time our hypothetical cohort of thirty-five-year-olds reached fifty, for example, they would have much better information about their life expectancy. Those that were relatively healthy would have an incentive to drop their original policies and seek a new policy with a different company at a lower annual rate. The remaining policies would then become losing policies for the company. (We are assuming here that, as is usual, the policies oblige the company to continue providing insurance to the policyholder so long as the latter continues to pay premiums at the originally contracted rate. Any other approach would, of course, provide undesirable incentives for the insurance company

5. In the mid-nineteentls century, when mutuals were first becoming well established in the life insurance industry, the managers of both mutual and stock companies evidently had very little idea about the prices they should charge or the amount of reserves they should maintain if they wanted to staly in business (Stalson: 225-26). 
'to drop policyholders whose health begins to look frail.) As a consequence, 'life insurance policies have a heavy front-end load: premium payments in the early years of the policy are substantially in excess of the cost to the company of providing insurance for those years, so that the policyholder stands to lose considerably if he abandons the policy at any point. In fact, the conventional life insurance policy, whether for term insurance or for the whole of life, has always provided for level premiums throughout the duration of the policy. To be sure, contemporary life insurance policies have cash surrender values. To avoid adverse selection, however, these values are typically well below the accumulated value of the premiums already paid (McGill: 61). Moreover, in the mid-nineteenth century, when the market share of the mutuals was at its maximum, life insurance policies had no cash surrender value (Stalson: 315-25).

Front-end loading of premiums effectively copes with the adverse selection problem. But by locking the policyholder into the policy, this tactic eliminates the use of exit as a means of policing the behavior of life insurance companies. Consequently, life insurance companies have an added incentive to behave opportunistically toward their policyholders. For example, the company could, if not effectively barred by easily enforceable contractual provisions, draw down its reserves or increase the riskiness of its investments without much fear of losing policies, even if the resulting increase in risk were apparent to the policyholders. The sale of new policies might be impeded; but this would not deter a company interested in pursuing an endgame strategy.

\subsection{IMPLiCATIONS FOR MUTUALS}

In sum, unregulated market contracting is unlikely to lead to efficient outcomes in the life insurance business. There are two alternatives for dealing with such market failure that have historically been important. The first is regulation; the second is the formation of life insurance companies on a mutual basis.

Today there is a well-established system of state regulation of life insurance companies. This system, which is relatively uniform among the states, does not attempt to control prices for life insurance policies, but rather concentrates on controlling reserves. Insurance companies are required to maintain reserves adequate in amount to cover their foreseeable liabilities for claims, and to invest these reserves in assets of a risk level sufficiently low to keep to acceptable levels the probability that reserves might at some point fall substantially in value. Because of the great difficulty, described above, of stating an unambiguous rule that clearly defines an acceptable reserve policy, state insurance commissioners maintain substantial discretion to use their judgment in determining the minimum reserve level for individual companies. This system of regulation seems to work relatively well today; it 
is presumably an essential prop maintaining the market for policies issued by those insurance companies (accounting for roughly half of the life insurance sold today) that are organized on a stock basis.

The mutual form of organization is, however, another solution to the market failure problem. With the mutual form there is no class of shareholders with an interest adverse to that of the policyholders; consequently, the incentive for the company to behave opportunistically in setting the level or riskiness of reserves is substantially attenuated. A mutual company can set a nominal premium rate that is high enough to provide reserves adequate for the most pessimistic forecasts of mortality, market rate of return, and inflation; then, if and when events turn out better than a worst-case forecast, the excess reserves can be liquidated and returned to the policyholders as dividends. The difficulty of market contracting between companies and policyholders is eliminated simply by eliminating the market and replacing it with an ownership relationship. ${ }^{6}$

\subsection{The Costs of the Mutual Form}

There are, of course, costs as well as benefits to the mutual form. We have already noted, for example, that the number and geographic dispersion of policyholders in most mutuals has led to substantial shareholder apathy, with the result that effective control of the mutuals is entirely in the hands of their directors and managers. Since these directors and managers are also free of any sanction from the market for corporate control, which may provide some check on the activity of the managers of stock insurance companies, one could reasonably expect the mutual insurance companies would be less effective in minimizing costs than would their proprietary counterparts. In fact, the evidence suggests that the mutuals often accumulate financial reserves-at the expense of their policyholders-that substantially exceed what is necessary to insure solvency. These reserves are evidently used in part to finance growth (which may benefit the management but is unlikely to benefit the existing policyholders who are financing it) and in part simply to satisfy management's desire for a comfortable margin within which to maneuver and a large portfolio to oversee (Hetherington). Moreover, profits accumulated from policyholder premiums are the only substantial source of capital available to a mutual company. Consequently, mutuals are constrained in their ability to expand their services in response to growing demand. Mutuals are also handicapped in their ability to diversify, both by state regulation that limits an insurance company's authority to engage in other business (stock companies form holding companies to avoid

6. Mavers and Smith (425-28) also note this explanation for the evolution of mutual insurance companies. In their brief treatment of the issue, however, they do not distinguish between life insurance and property/liability insurance. As indicated by the discussion here and below, this explanation is far more persuasive for the former type of insurance than it is for the latter. 
such regulation, a tactic not available to a mutual) and by the problem of access to capital just mentioned (Dannen).

On the other hand, when we consider the factors, discussed in section 2, that bear on the costs of establishing customer control in an industry, we see that there are several reasons to believe that-with the important exception of customer apathy - the insurance industry is reasonably well suited to the mutual form. For one thing, the amounts of organization-specific capital needed in the industry are small. For another, the customers involved all purchase a highly homogeneous product from the firm, and thus there is little conflict of interest among them; the only potentially serious problem in this respect is wealth shifting among generations of policyholders through accumulation of reserves.

\subsection{Testing Theory against the Historical Recond}

Whether the mutual form adds any important degree of protection from market failure today, now that actuarial science is relatively reliable and a well-tested system of reserve regulation is in place, is unclear; we shall return to this question below. But there is strong evidence that, when life insurance first began to be marketed in the United States, the mutual form arose precisely to deal with the types of market failure described here.

Life insurance first began to be sold to the public at large around 1810 . From then until 1843, a number of companies, all organized on a stock basis, began to sell life policies. The only companies among these that had any success in selling policies were roughly half a dozen large companies, organized after 1830, that combined the sale of life insurance with the management of trusts. For the latter companies, the sale of life insurance was essentially a sideline; trust management was their primary business. These life and trust companies were all well capitalized, conservatively managed, and of unquestioned financial soundness. Nevertheless, even the most successful of them succeeded in selling only several hundred life insurance policies in total (Stalson: 83-99, 110, 227-28).

In 1843 the first mutual life insurance company serving the public at large was formed, and six more mutuals (but no new stock companies) entered the business by 1847 . These companies proved much more successful than their proprietary predecessors. All seven companies remain in business today and are among the largest of the mutuals; in contrast, all but two of the stock companies selling life insurance in 1843 had withdrawn from the business ten years later, and the activities of the remaining two had been substantially curtailed (Stalson: 103-25; Knight: 105). By 1849, nineteen mutuals were in business (Stalson: 750). During these years, actuarial tables were crude and reserves were almost totally unregulated. Thus there was no effective alternative to the mutual form for dealing with the inadequacies of the market. 
Further evidence that the mutual form arose in this period as a means of dealing with the problems of long-term contracting under uncertainty described above comes from the types of policies being written during this period. Prior to 1843 , most of the life insurance policies being written were in the form of term insurance for relatively short one-year and seven-year terms. By 1859, after the establishment of the mutuals, whole life policies had come to represent more than 90 percent of the business (Stalson: 83-99, 118; Knight: 101, 118).

State regulation of insurance company reserves and investment policies began in the 1850s and was refined and spread among the states in the 1860s (Stalson; 292-315). That such regulation served as a substitute for the mutual form in providing a response to market failure is reflected in the fact that stock companies began to gain substantially in market share during this period, in contrast to the previous experience.

The increased reliability of mortality tables that has come with time, together with the increased sophistication of the systems used to regulate life insurance company reserves, may by now have made stock companies quite as reliable as mutual companies; thus the mutual form may no longer serve an important function in this market. Indeed, this may have been true half a century ago or earlier; it is not obvious, from an examination of the development of the life insurance industry since 1920, that since then market forces have given an important evolutionary advantage to the mutual form, and there is evidence that in recent decades the stock form may have become the more viable of the two.

In the first half of this century, there were a number of conversions of stock companies into mutual companies. Early in the century, three of the largest stock companies-Metropolitan, Equitable, and Prudential-converted to the mutual form, and today these companies are among the largest of the mutuals. The latter mutualizations were evidently inspired to some degree by journalistic muckraking and governmental investigations (including, most notably, New York's Armstrong Commission [1905]) that exposed dubious marketing practices and managerial self-dealing in the life insurance business and called for the mutualization of all stock companies - -even though it was not entirely clear that abuses were particularly more prevalent among stock than among mutual companies (Buley: 199-205; Grant: 37-46; Nelli and Marshall: 27-32). The extent to which such exposés reflected, or stimulated, public opinion against stock companies and thus indicated that mutuals would find it easier than stock companies to sell policies in the ensuing years is difficult to judge (Stalson: 558-59). In any event, there is evidence that Equitable's conversion to the mutual form was also motivated in substantial part by its managers' desire to avoid a corporate takeover (Grant: 36). And such a desire to insulate management from the threat of takeover may also have been an important stimulus to other mutualizations that took place in subsequent years. At least fifteen 
stock life insurance companies were mutualized in the period 1900-36 (Stalson: 759 ).

There were also, however, a number of conversions of mutual life insurance companies into stock companies in this period: from 1900 to 1936 there were at least seventeen such "stockings"-more than the apparent number of mutualizations. These conversions were evidently motivated in part by the desire to achieve greater access to capital or by the desire to diversify (Josephson: 99-100, 102; Kelley: 29). They may also, like the mutualizations, have been motivated to some extent by the self-interest of the companies' managers, who found it easy, in the course of such conversions, to obtain stock for themselves representing a substantial fraction of the company's net worth (Hetherington). In any event, such conversions suggest that the market was not, on balance, working strongly to select for the mutual form.

Evidence that the mutual form may have become anachronistic in the life insurance business is even stronger for recent decades. The mutuals' share of life insurance in force has fallen from 69 percent in 1947 to 43 percent in 198.3 (Nelli and Marshal: 35 n. 5; Best's Insurance Reports, Life-Health: x). The number of mutual life insurance companies declined from its recent highpoint of 171 in 1954 to 135 in 1981, while the number of stock life insurance companies increased from 661 to 1,823 during the same period. The two conversions from stock to mutual that took place in the fifteen years between 1966 and 1981 were matched by five conversions from mutual to stock (American Council of Life Insurance: 90 ).

Two econometric studies of the cost structure of the life insurance industry have been published, employing data from the 1960s and 1970s (Houston and Simon; Geehan). Although both studies are primarily concerned with exploring economies of scale, they include in their regressions a dummy variable reflecting the stock versus mutual form of organization. Neither study finds that the organizational form has a significant effect on average costs. This suggests that if the mutual form is less efficient than the stock form today (as suggested by the mutuals' shrinking market share), it is not owing to weaker incentives to minimize costs, but rather to other factors such as restricted access to capital and inability to diversify.' The latter conclusion is

7. On the other hand, these two studies do not control for the riskiness of the firms involved. If the policies written by the stock companies are, on average, riskier than those written by the mutual companies (because, for example, the stock companies are more likely to go bankrupt eventually), then these results are also consistent with the conclusion that the mutuals continue to be more efficient overall than the stock companies. As it is, systematic data comparing failure rates for mutual and stock life insurance companies in this century seem not to have been assembled. However, the protagonists of the mutual form, including the mutual companies themselves, do not claim today that a lower risk of defaulting on policies constitutes a reason for purchasing a life insurance policy from a mutual rather than a stock company. Consequently, it seems unlikely that the failure rate of mutual companies is conspicuously lower than that for stock companies, and even less likely that consumers' lack of faith in the reliability of the stock companies is today an important source of the market demand for policies written by mutual companies. 
reinforced by the fact that large numbers of policies have recently been transferred from mutuals to stock companies via coinsurance agreements (although this phenomenon may also reflect tax incentives) and that mutuals have begun to charter stock company subsidiaries, generally for the purpose of writing specialty lines of insurance (Best's Insurance Reports, Life-Health: $\mathrm{x}$ ). It is also reinforced by the fact that the needs to obtain capital and to diversify are commonly cited as the major reasons why a number of the largest mutuals are today seriously considering conversion into investor-owned firms (Dannen).

\subsection{The Analogy to Long-Term Bonds}

Long-term bonds present a contracting problem rather similar to that presented by life insurance. ${ }^{5}$ Corporate bonds not infrequently have maturity dates of twenty or thirty years from the date of issue. Once the company has issued such bonds, it has an incentive to deplete its assets, encumber them with other debt obligations, or devote them to unusually speculative enterprises. The purchasers of such bonds obviously have an interest in preventing the company from pursuing such policies. Yet the bondholders are often individuals without the ability to keep personal track of the affairs of the issuing company. Of course, if the issuing company expects to issue further bonds in the future, reputational effects may be sufficient to prevent it from acting opportunistically in the use of its assets. But the company can always act in the hope that its high-risk financing strategy will pay off. And, as in the case of life insurance companies, there will always be the temptation to pursue an endgame strategy.

Yet market contracting works reasonably well for corporate bonds. Why, then, will it not work as well for life insurance policies?

Perhaps the most important element distinguishing bonds from life insurance contracts is the institution of the trust indenture and the bond trustee. In recognition of the fact that individual bondholders are in a poor position to monitor the issuing company's behavior on their own, the rights of bondholders to monitor the corporation are aggregated in the hands of a trustee who is empowered to act on their behalf. The trustee is generally a bank or other institution of sufficient size and sophistication to undertake such a monitoring role and to have a reputation that would be impaired if the role were performed poorly. Bonds are issued subject to a trust indenture that commits the issuing corporation to elaborate and detailed covenants designed to insure that the value of the corporation's assets will be mantained during the life of the bonds. It is the trustee who monitors compliance with

S. Mavers and Smith (425-26) also note the analogy between bondholders and insurance policyholders in general. 
the indenture; the various covenants of the indenture are typically not even copied over onto the bonds issued under it, in recognition of the fact that the typical bondholder is not in a position to understand, much less police, the commitments involved.

Why has the institution of the indenture and the trustee arisen for bonds and not for life insurance? The most important reason is probably that bonds are generally not issued continuously by a company, as life insurance policies are, but instead are sold relatively infrequently and in large issues. (If life insurance companies were more like our hypothetical company above, which insured a single large cohort of thirty-five-year-olds, they would be more analogous to issuers of bonds in this respect.) Each issue of bonds sold by a given corporation has its own indenture and trustee, appropriate to the time and circumstances under which the bonds were issued. A trustee for a given company's life insurance policyholders would presumably have to represent all of the company's policyholders, regardless of the time at which the individual policies were issued. The trustee would presumably have to be appointed at the time the life insurance company was created and would have to serve throughout the life of the company. Given that the trusteeship would cover all policies sold by the company in the past and to be sold by it in the future, there would be considerable difficulty in drafting a detailed set of covenants, analogous to the bond indenture, to which the company would be committed and that the trustee would be empowered to enforce; any covenants would have to be quite general in form.

In essence, we can view the mutual life insurance company as an institution that creates just such a trustee and combines its role with that of the issuing company. Under the mutual form, the company itself becomes a trustee for its policyholders: the fiduciary duties of a mutual insurance company's management, like those of the trustee under a bond indenture, are owed to the company's policyholders rather than to a separate class of investors with interests opposed to those of the policyholders.

Other factors besides the institution of the trustee and the trust indenture also provide interesting contracts and comparisons with the market for life insurance. For example, bonds are typically sold through underwriters and brokers (who can also influence the choice of trustee). These firms have their own reputations to protect and thus can be relied upon to some extent by bond purchasers. Insurance agents presumably play a somewhat similar role in the life insurance market. The agency system became widespread in this country in the latter half of the nineteenth century, and its development may help to explain the increased viability of stock life insurance companies that became evident in that period.

Another element that has helped support the bond market is the fact that portions of bond issues are often purchased by large institutional investors, which are in a position to look out for their interests. Small bondholders get 
the benefit of the monitoring that is undertaken by such large purchasers. In the life insurance market an analogous role is perhaps being played today by companies that purchase group life insurance for their employees. The sophistication of these companies as purchasers presumably benefits not only their employees but also individuals who purchase policies on their own from the same companies. The increasing share of the market represented by group life insurance therefore may also help to explain the decreasing role of mutuals in recent years.

Bondholders are presumably also less risk averse as a class than are life insurance policyholders, since the former can hold the bonds issued by any given company as a small part of a diversified portfolio. Life insurance purchasers can, and sometimes do, hold life insurance policies from more than one company, but the transaction costs of this strategy are relatively high.

Finally, it would be a mistake to think that bond transactions, unlike life insurance transactions, take place unproblematically in a system of unregulated markets. In the first place, the bond market, like the life insurance market, is regulated: the Trust Indenture Act of 1939, 15 U.S.C. $\S 77$ aaa et seq., establishes minimum requirements to which a trust indenture must adhere. Moreover, most corporate capital in this country is held, not in the form of bonds, but rather in the form of common stock-and by purchasing common stock an investor becomes a part owner of what is essentially a capital cooperative, or investors' (lenders') mutual.

\subsection{Alternative Theories}

The problem of policing reserves described above is undoubtedly not the only factor that has led to the development of mutuals in the life insurance industry. I shall here sketch briefly several other considerations that may play a role.

Incomparability of policies. Life insurance companies today engage ir substantial product differentiation: policies offered by different companies differ in terms of the scheduling of premiums, cash surrender values, loan values, rights to purchase additional insurance, convertibility into other forms of insurance, and so on. As a consequence, it is not entirely easy to compare the prices offered by different companies, and thus the effectiveness of market competition in assuring prices close to cost is limited. It may be that some consumers, faced with this problem, choose to patronize mutual rather than stock companies as a means of assuring that they are getting a price that does not contain excessive pure profit for the issuer of the policy.

Whatever the validity of this theory as applied to today's market, it does not seem persuasive in explaining the historical emergence of the mutuals. In the 1840s and 1850s, when the mutuals first arose and came to dominate 
the market, the terms of policies were remarkably uniform. Companies issued level premium, whole life policies with no cash surrender values or other complications, based the premiums solely on age, and published the premium schedules in their advertisements. There was no difficulty in comparing the terms of policies across companies, and competition in fact caused prices to be quite uniform amòng companies (Stalson: 126-55, 323-24).

Risk aversion on the part of investors. When a person buys life insurance, he is primarily seeking to insure himself against the possibility that he will live a shorter life than the average person. This is a risk that can be fairly inexpensively eliminated by pooling, and such pooling is of course the primary function of life insurance companies. Presumably a purchaser of life insurance has much less interest in insuring himself against the possibility that the average lifespan of people in his generation will be different than expected. A stock life insurance company, however, stands to make or lose money based on its accuracy in estimating average life expectancy. The crude state of actuarial science in the first half of the nineteenth century made the risks associated with estimating average mortality very high ones for stock life insurance companies, and investors in such companies could be expected to charge a large premium for bearing this risk. ${ }^{9}$ But if they had an alternative, life insurance policyholders would presumably not have much interest in paying a large additional premium to be protected against the risk. And the mutual insurance company presented such an alternative. ${ }^{10}$

A conventional life insurance policy issued by a stock company also involves a gamble between the policyholders and the company's investors over the future rate of inflation. Yet, like other gambles, this will in general simply increase the aggregate risk faced by both groups, and therefore is inefficient. The mutual form avoids such a gamble.

Finally, policies issued by stock companies provide insurance concerning the long-run rate of return to investments in the economy. Again, as with av-

9. The proprietary life and trust companies that sold life insurance in the 1830 s charged premiums for life insurance that were 50 percent higher than those charged by mutuals that were established a decade later (Stalson: 323-24), and, as we have seen, nearly all of them abandoned the business when the mutuals came on the scene and competition forced prices down. There is also some evidence that the widespread bankruptcies in the fire insurance business after the great New York fire of 1835 discouraged investors from all forms of insurance, including life insurance (Stalson: 109).

10. Mayers and Smith state that "our analysis suggests that . . . if the cost of controlling management in mutual insurance companies is higher than in stock firms, then mutuals should be more prevalent in lines of insurance where management exercises little discretion in setting rates (i.e., in lines of insurance for which there are 'good' actuarial tables)" (427). This conclusion overlooks other factors that press strongly in the other direction. For the reasons suggested in the text here and in section 3.1, it seems that instead one should expect to find that mutuals have a stronger comparative advantage to stock firms where the actuarial tables are least reliable. A similar conclusion holds for property and casualty insurance; see section 4.7 . 
erage mortality, it is not obvious that this is a form of insurance that is terribly valuable to the average individual, whose welfare (and whose survivors' welfare) is probably more dependent on their relative standing in the economy than on their absolute level of wealth. In any event, the risk involved obviously cannot be diversified through the capital markets but can only be shifted from policyholders as individuals to investors as individuals, a transaction that promises only modest efficiency gains at best.

\subsection{Why Do Mutuals Continue to Survive?}

The preceding discussion has suggested that, while the mutual form had an evident competitive advantage over the stock form in the mid-nineteenth century, it is not obvious that such a competitive advantage still exists today. Why, then, does the form still survive?

For one thing, as we have seen, it does not appear that the mutual form is significantly inferior to the stock form in the area of cost minimization. Rather, the comparative advantage of the stock form seems to be in access to capital and opportunities for diversification. Yet these are not advantages that are likely to drive existing mutuals out of existence. Moreover, a hostile takeover of a mutual company through a tender offer or a proxy fight is essentially an impossibility. Thus a mutual company will convert to the stock form only if the management desires the change. Yet the incentives for management to wish such a change are limited, for it will expose them to the market for corporate control.

It is possible that tax incentives have also played a role in perpetuating the mutual form, though it is not at all apparent that they have been a significant factor. Since there was no corporate tax throughout most of the nineteenth century, it obviously was not important in the initial shaping of the industry. For several decades preceding the enactment of the Life Insurance Company Income Tax Act in 1959, the federal corporate income tax may have provided an implicit subsidy to the mutual versus the stock form. This was not clearly the case, however, and if such a subsidy existed it must have been quite modest, since the taxes collected from the life insurance industry in general were small in that period. The 1959 act was designed to increase the taxes collected from the industry but was also apparently designed to assure equality in the tax treatment of stock and mutual companies. As events unfolded, the latter act may actually have led to some tax bias against the mutual form (Clark: 1637-64.)

\subsection{Participating Policies}

The ultimate success of stock companies in competing with the mutuals may be due not just to the development of regulation and improved actuarial 
tables, but also to the efforts of stock companies to develop contracts that mimic some of the features of the mutual form. In particular, stock companies early on came to offer "participating" policies, under which the policyholder shares with the company some of the net returns that the latter obtains from investing the policy premiums. On the other hand, such participating policies are themselves difficult for policyholders to evaluate and are today the subject of regulation in many states."

\subsection{COMParison WITH NONPROFITS}

If, as has been argued here, the development of mutual companies in the life insurance industry is in major part a response to the difficulty in writing a long-term contract that provides adequate security to policyholders, then mutuals in this industry play a role that has more in common with that of nonprofits than with that of other types of consumer cooperatives. That is, mutual life insurance companies are essentially a response to contract failure-the inability to use ordinary contractual devices to monitor quality of performance-rather than to monopoly.

This view of mutual life insurance companies is in keeping with the fact that their structure and behavior are in important respects closer to those of nonprofit firms than to those that characterize other consumer cooperatives. For example, the board of directors of such companies is essentially selfappointing; the members have no effective right to distribute to themselves the accumulated surplus of the organization; and the companies, like many nonprofit educational and religious organizations, accumulate large surpluses (endowments) with which they insulate themselves from the pressures of the market. Like the patrons of a typical nomprofit, the policyholders in a mutual company derive protection not from the exercise of control over the firm, but rather from the fact that the management of the mutual, unlike the management of a stock company, does not have a strong pecuniary incentive to exploit its policyholders. ${ }^{12}$ There are, indeed, some large non-

11. That participating policies in themselves are insufficient to make stock companies competitive with mutual companies is evidenced by the fact that the first stock company to issue participating policies did so in 1836 , before the advent of the mutuals, and nevertheless did not do a particularly successful life insurance business (Stalson: 94-97).

12. Hetherington argues that, since the policyholders in a mutual life insurance company in fact do not enjoy the usual attributes of ownership-namely, effective participation in net earnings and control-there is no reason to place obstacles in the path of managers of mutuals who wish to convert the firm to the stock form, even if the result of transaction will be, as it apparently often has been, that the management will capture for themselves a substantial share of the firm's accumulated net surplus. The policyholders, he suggests, cannot be hurt by losing what they never had. This reasoning is not, however, valid if the mutual companies continue to play a fiduciary role vis-à-vis their policyholders of the same sort that nonprofits play toward their patrons. In that case, letting the management turn a mutual into a stock company is on the same order as letting the management of a nomprofit university convert it into an investor-owned company while capturing for themselves a substantial fraction of the university's endowment. 
profit life insurance companies; TIAA is one familiar to most scholars.

As we shall see below, similar conclusions do not hold for mutual companies in the property and liability insurance industry. Their historical role, in contrast to that of mutual life insurance companies, seems much closer to that of other consumer cooperatives than it is to that of nonprofits.

\section{PROPERTY AND LIABILITY INSURANCE}

The problems of long-term contracting that help to explain the evolution of mutuals in the life insurance business apparently do not explain the important role of mutuals in property and liability insurance. Most property and liability insurance is sold under relatively short-term contracts, commonly with a duration of a single year. To be sure, changes in technology have caused some of the risks now covered by property and liability insurance to become long-term ones. Thus, a company that writes liability coverage for a chemical plant for a given year may find that it is called upon to pay claims for cancers that only appear decades later. But the technological changes responsible for this situation are relatively recent ones and are long antedated by the development of mutual insurance companies in this area.

Rather, to understand the role of mutuals here we must turn to other forms of market failure, both natural and artificial.

\subsection{Avoiding Regulation}

One likely inducement to the survival of the mutual form in this industry is rate regulation. Although there have recently been substantial moves toward deregulation, property and liability insurance, unlike life insurance, has historically been subject to state regulation that establishes minimum rates for different types of policies. As applied to mutual insurance companies, such regulation commonly extends only to gross premiums - that is, to the nominal premiums that an insurance company charges its policyholder prior to determining any dividend that is owed them. Thus the dividends paid by the mutuals are a means of undercutting rate regulation (General Ins. Co. of America v. Earle, 65 P.2d 1414, 1416-17, Ore. 1937; Kimball and Denenberg: 226 n. 38).

Rate regulation was most rigid during the 1950 s and 1960 s, and there is evidence that this rigidity contributed to the growth of mutuals during that period. For example, the growth in mutual fire insurance from 14 percent of the market in 1951 to 20 percent of the market in 1970 has been attributed to the greater rate flexibility that dividends afforded the mutuals (Heflebower: 167). Rate regulation by the states did not begin until this century, however, while mutuals were already common in the eighteenth century and experienced their most spectacular growth in the nineteenth century. Moreover, 
mutuals have contined to thrive in states without regulation. Thus avoidance of rate regulation cannot be anywhere near the whole story.

\subsection{The Evolution of the Mutuals}

In order to understand the other factors that have given rise to mutual companies in the property and liability field, it is helpful to understand the circumstances of their origin.

In property and liability insurance, as in life insurance, the nineteenth century was the high point for the formation of mutual companies. Moreover, the circumstances in which the successful mutuals arose were remarkably uniform. The stylized facts are roughly as follows: owners of firms within a particular industry and a particular region-say, cotton textile mills in Rhode Island, or flour mills in Iowa, or farms in a township in Indiana-who believed they presented unusually low risks of fire would find themselves paying fire insurance premiums to stock companies that they considered excessive. After trying unsuccessfully to persuade the stock companies to lower their fire insurance premiums, they would finally band together to form a mutual company to insure themselves. The resulting net premiums would be far below those charged by the stock companies. Unlike the stock companies, the mutual would (1) insure only the better risks in the industry and (2) have a regular program of inspecting the firms they insured, both to assess the risk and to recommend loss prevention measures (Bainbridge; Manufacturers Mutual Fire Insurance Company).

From this pattern, we can discern several likely explanations for the success of the mutual companies. The following discussion will explore these in turn.

\subsection{ASYMMETRIC INFORMATION}

It was suggested above that the development of mutual life insurance companies was attributable in part to the fact that prospective policyholders have difficulty in obtaining the information necessary to distinguish among insurance companies that differ in their riskiness. In the case of property and liability insurance, the situation seems to be the reverse: mutual companies evidently arise in part because insurance companies cannot distinguish easily between prospective insureds that differ in the risks they present.

The prospective customers for any given line of insurance-for example, fire insurance for textile factories-are likely to vary considerably in the degree of risk they present. Moreover, the customers themselves are often likely to have better information than the insurance companies on this matter. If this were all there is to the problem of asymmetric information here, then one might expect adverse selection to undercut the viability of the mar- 
ket, but there would be no particular reason to expect mutual companies to evolve in place of stock companies. It also seems plausible, however, that one textile company, by virtue of what it knows about the business, will commonly be in a better position to assess the risk of fire presented by another textile company than will any firm, including any insurance firm, that is not itself in the textile business. Or at least it seems probable that this was the case in the mid-nineteenth century, when the formation of mutuals was at its relative peak. Long-term experience tables and other systematic means of estimating expected losses were then generally unavailable to insurance companies. The firms that joined to form the mutuals, on the other hand, were commonly owned and operated by individual entrepreneurs, who necessarily were already quite familiar with the available technology in the industry and the risks that it presented. This situation then provided an incentive for those firms within an industry that knew themselves to be unusually good risks to join together to form a mutual insurance company to insure themselves: the firms could recognize each other as good risks but would have difficulty convincing an insurance company from outside the industry that they deserve especially low premiums. Or, put differently, the cost of information about the riskiness of individual insureds was lower to firms within the industry than to those outside of it.

To be sure, this theory in itself does not explain why a single firm within a given industry would not exploit its inside information about the industry by going into the insurance business itself rather than by joining with other firms to form a mutual. To understand this, we need to explore some additional considerations.

\subsection{Limited COMPETITION}

In the nineteenth century, property and liability insurance seems to have been a relatively local business, presumably owing to the costs of communication. Consequently, given the economies of scale associated with the diversification derived from writing large numbers of policies, there was presumably insufficient room for the development of a substantial number of competing insurers with detailed knowledge of a given industry. Thus, even if a stock company had succeeded in developing the expertise needed to rate accurately the risks presented by a given type of local industry, it would have had little or no competition. And this, in itself, would create an incentive for the firms buying insurance to form a mutual.

The absence of competition may have been reinforced by the relative absence of price discrimination that characterizes the insurance industry. For various reasons-presumably including the costs of information and administration and of haggling with customers-insurance companies commonly do not adjust their rates to the specific risks presented by individual custom- 
ers, but rather charge the same rate to all customers who fall within a given broad category. Indeed, there is evidence that at the time that the mutuals were formed, a given stock insurance company would commonly charge the same rate to all risks of a given type (such as cotton textile mills) that it insured (Manufacturers Mutual Fire Insurance Co.: 33). Consequently, a firm seeking insurance could not get stock companies to compete for the firm's individual business on the basis of price (that is, the firm could not get a stock company to compete for the individual firm's business by offering a special lower price for that firm alone). Rather, competition among firms could only take place among whole categories of insureds. With few insurance firms of fering policies, such competition was unlikely to be intense. ${ }^{13}$

\subsection{INSPECTION AND SAFETy RESEARCH}

For many types of risks, close (and sometimes recurring) inspection of the insured is advantageous in assessing the risk, in discouraging moral hazard, and in suggesting to the insured further means of risk reduction. By these means, inspection can reduce the net cost of insurance. There are, however, disincentives to undertake inspections when the insurance company is organized as a stock company rather than as a mutual.

To begin with, inspection represents a transaction-specific investment by the insurance company. Since insurance contracts are short-term, this leaves open the possibility for the insured to act opportunistically, threatening to take its business elsewhere unless it is given unremuneratively low rates. Longer-term contracts might obviate this problem but would presumably require excessive rigidity in rates or grant excessive discretion in rate setting to the insurer. And any effort to deal with the problem by having the insured pay separately for the inspections would simply put the shoe on the other foot. (See Williamson, 1979; 1983.)

Moreover, a stock insurance company has only a limited incentive to encourage its policyholders to undertake investments in cost-justified loss pre-

13. Moreover, where individual insurance companies charge the same rate to all firms they insure, both insurance companies and their customers have an incentive to sort themselves out so that the companies presenting the best risks go to one insurance company, which has the lowest rate, while the next best risks go to another company, which has a somewhat higher rate, and so forth. But then, if the company with the lowest-risk customers is a stock company, it will have an incentive to charge a premium that is almost as high as that charged by the company with the next-lowest-risk customers, since the latter company is the former company's closest competition. In other words, the first company has a monopoly of sorts on the lowest-risk customers and thus has an incentive to exploit them. It follows that the lowest-risk customers have an especially strong incentive to form their own mutual company, so that they will not be subject to such exploitation. (For a formal model of this process, and a discussion of a number of other contexts in which such stratification of customers gives rise to an incentive for forming cooperatives, see Hansmann, 1984.) The available evidence does not make it clear whether in fact such stratification of policyholders among stock insurance companies was evident in the nineteenth century. 
vention measures so long as a large proportion of the benefit of such investments will be returned to the insured in the form of a reduction in premiums. And, on the other hand, if loss-prevention measures taken by the insured are not so rewarded, there is insufficient incentive for the insured to undertake them when they are suggested.

The mutual form mitigates such conflicts of interest between the insurer and the insured. In fact, as I have already noted above, the early mutual companies were distinguished by much more active inspection programs than were characteristic of the stock companies, and this difference in behavior presumably helped provide the mutuals with a competitive advantage.

The early mutuals also were distinguished by a more active program of research into loss-prevention measures than were the stock companies. Since such research is a public good for the industry in which the insureds operate, a mutual obviously has much greater incentive than a stock company to undertake it. Such research would presumably afford a mutual a competitive advantage, however, only to the extent that its fruits were available to the firm's policyholders more quickly than to the insured industry at large.

\subsection{Avoiding Moral Hazard}

Some of the smaller mutuals also evidently serve the useful purpose of reducing losses due to moral hazard. In particular, this seems to be true of the local farm mutuals. These organizations had their heyday in the last quarter of the nineteenth century - there were over 1,400 at the century's end (Bainbridge: 171) - but continue to play an important role today. Though many are too small to diversify risk with optimum efficiency, they evidently serve the useful purpose of reducing moral hazard by virtue of the fact that many of the policyholders are neighbors (Heubner and Black: 507).

\subsection{BEARING INDUSTRY-WIDE RISKS}

There are problems of risk sharing in property and liability insurance that parallel those discussed above with respect to life insurance. The purchasers of mutual property and liability insurance-which are generally businesses -are primarily interested in insuring against concentrated losses to their own enterprise. They presumably have much less interest in avoiding risks associated with the industry as a whole. A mutual company consisting of members of the same industry pools risks within the industry, so that all firms covered by the same insurer will experience the same costs each year. Consequently, no firm will gain a competitive advantage through the insurance; presumably all firms will simply pass along most or all of the insurance costs to their customers. Fluctuations in the net cost of insurance each year 
will have the same character as fluctuations in any other factor cost faced by the industry as a whole.

A stock insurance company that insured the same firms, however, would have to bear the risk associated with the loss experience of the industry as a whole, and the owners of the company would presumably require substantial compensation for bearing this risk. Thus the firms in the industry are likely to find it less expensive to insure themselve through a mutual.

This issue will be most important in those industries in which the loss experience of the industry as a whole is most difficult to predict. New industries, or old industries in new locations, are the most likely to be in this category. This may help to explain why the mutual companies had such a strong competitive advantage over the stock companies in the mid-nineteenth century, when experience with industrial insurance was still quite limited, and why farm mutuals were so common in frontier farming communities (Bainbridge: 162).

\subsection{Cartelization}

As early as 1840 , property and liability insurance companies began conspiring to set rates through the formation of voluntary rate bureaus (which also served as a means to share experience concerning loss rates). Such cartelization presumably contributed to the limited competition and high prices that provided the impetus for the mutual companies in this industry. It seems likely, however, that this factor has been more important in the twentieth century than it was during the formative stages of the industry in the nineteenth century. The success of price-fixing was evidently limited throughout the nineteenth century owing to the repeated disintegration of the cartels and to hostile state action. It was only in this century that many states turned from fighting to aiding the rate bureaus. Moreover, the property and liability insurance industry has been exempt from the federal antitrust laws throughout most of its history. Consequently, effective competition has generally been limited for most of this century even when there have not been state-established minimum prices (Heflebower: 165-71; Weber).

\subsection{HoMogeneity OF MEMBER INTERESTS}

The cost-of-control considerations discussed above in connection with life insurance generally apply equally in the property and liability insurance industry. The particular importance of homogeneity of interests among the members of a mutual is especially obvious in the case of property and liability insurance, however. As opposed to the stock firms, the mutuals in this industry commonly do not insure firms in more than one line of business, even 
though such diversification would have the advantage of spreading risk. The reason for this is apparently that, as suggested in section 2, the costs of operating a cooperative increase dramatically when all the members are not purchasing the same thing from the firm and thus may have conflicting interests.

This consideration presumably explains why the structure of the mutuals in the property and liability insurance industry is so different from that in the life insurance industry. In the latter industry, proprietary firms far outnumber mutuals, but the mutuals are generally much larger and do a disproportionate amount of the total business. In property and liability insurance, on the other hand, the situation is just the reverse: mutuals outnumber the proprietary firms (MacAvoy: 8), but the proprietary firms are commonly larger and do roughly three-quarters of the industry's business. One recent text suggests that this difference is a product of history: the older (and thus larger) life insurers are mutual, while the older (and thus larger) property and liability insurers are stock companies (Mehr and Cammack: 90). This logic is, however, quite unconvincing. ${ }^{14}$ Rather, the evident reason for the disparity is that life insurance is a far more homogeneous commodity than is property and liability insurance. ${ }^{15}$

\subsection{The Continuing Survival of Mutuals}

It seems likely that in property and liability insurance, as in life insurance, the mutual form has to a degree become anachronistic. Transportation and communication costs have declined significantly since the last century, with the result that most insurance markets are now national in scope. Moreover, as experience has accumulated, and as insurance companies have come to share their loss experiences, it has presumably become far easier for companies of all types to assess the risk presented by any given applicant for insurance. As a consequence, the environment for effective competition in

14. Such reasoning places a great deal of faith in the ability of companies to maintain their market share over periods of more than a century. Moreover, it ignores the fact that the very earliest life insurance companies in the United States were all proprietary, while the very earliest property and liability companies were all mutuals (Bainbridge: 45 ; Manufacturers Mutual Fire Insurance Co.: 15-25).

15. Mavers and Smith state that "if it is less expensive to concentrate voting/control rights in small than large corporations, then the potential for stockholders to expropriate policyholder wealth is greater in small stock insurance firms. This implies that in a given line of insurance. the smallest firms (e.g., measured by total assets) should be mutuals" (427-28). As in the case of the same authors conclusions concerning the influence of actuarial risk (see n. 10 above), this reasoning seems to assign much too large a role to factors affecting the efficacy of direct stockholder control of management. Other factors, such as those discussed in the text here and elsewhere, seem far more important in determining the relative size of mutual and stock firms. 
property and liability insurance markets is now far better than it was in the nineteenth century, and the special protection afforded policyholders by the mutual form may no longer be a particularly significant advantage in most forms of property and liability insurance.

Some evidence to support this conclusion comes from the fact that mutual property and liability companies have come increasingly to look like their investor-owned counterparts. Effective policyholder control has long since disappeared in many mutuals. Moreover, many individual mutuals have extended their operations beyond the industry they were initially formed to serve and now insure risks in a variety of different industries (Heflebower: 162-76; Bainbridge).

Nevertheless, mutual property and liability insurers have continued to survive, and even to grow. For example, the share of the market for fire insurance held by the mutuals increased from 11 percent in 1900 to 20 percent in 1970 (Heflebower; 167). What explains this? As already noted, state rate regulation and state tolerance or encouragement of industry cartels (combined with federal antitrust exemption for the industry) served to give a competitive advantage to the mutuals in recent decades. Further, there is evidence that, even in the absence of regulation and cartelization, the mutual companies are still able to underprice their investor-owned counterparts in some lines of insurance (Helfebower: 162-76). Moreover, mutual property and liability insurance companies, unlike mutual life insurance companies, have had the advantage of a system of federal corporate income taxation that has been intentionally designed to favor them vis-à-vis stock insurers (Clark: 1650, 1664-75). Finally, as in the case of life insurance, it seems likely that the costs of operating in the mutual form rather than the stock form are not particularly high, and thus market forces will not tend to select strongly for the latter form even in situations in which the mutual form offers no special advantages.

\section{CONCLUSION}

Although mutual companies are common both in life insurance and in property and liability insurance, they evidently play rather different roles in these two industries. In property and liability insurance, their role is close to that which is commonly performed elsewhere by consumer cooperatives: they provide a measure of protection against noncompetitive pricing. In life insurance, on the other hand, mutual companies seem to have been important historically, not in protecting consumers from simple price exploitation, but rather in avoiding opportunistic behavior on the part of sellers in a situation in which adequate contractual safeguards could not be established. 


\section{REFERENCES}

Akerloff, G.A. 1970. "The Market for 'Lemons': Quality Uncertainty and the Market Mechanism," 84 Quarterly Journal of Economics 488-500.

American Council of Life Insurance. 1982. Life Insurance Fact Book. Washington, D.C.: American Council of Life Insurance.

Bainbridge, John. 1952. Biography of an Idea: The Story of Mutual Fire and Casualty Insurance. Garden City, N.Y.: Doubleday \& Company.

Belth, J. M. 1966. The Retail Price Structure in American Life Insurance. Bloomington: Bureau of Business Research, Graduate School of Business, Indiana University.

. 1969. "Author's Reply," 36 Journal of Risk and Insurance 495-96.

Best's Insurance Reports, Life-Health. 1983. Oldwick, NJ: A. M. Best Company.

Best's Aggregates and Averages, Property-Liability. 1972. Oldwick, NJ: A. M. Best Company.

Buley, R. Carlyle. 1953. The American Life Convention, 1905-1952. New York: Appleton-Century-Crofts, Inc.

Clark, Robert C. 1975. "The Federal Income Taxation of Financial Intermediaries," 84 Yale Law Journal 1603-82.

Dannen, Frederic. 1984. "Is Time Running Out for the Big Mutuals?" Institutional Investor 159 (June).

Fama, Eugene, and Michael Jensen. 1983. "Agency Problems and Residual Claims," 26 Journal of Law and Economics 327-49.

Fortune. 1983a. "The Fortune Directory of the Largest U.S. Industrial Corporations," 226 (May 2).

- 1983b. "The Fortune Directory of the Largest U.S. Non-Industrial Corporations," 152 (June 13).

Geehan, Randall. 1977. "Returns to Scale in the Life Insurance Industry," 8 Bell Journal of Economics 497-514.

Grant, H. Roger. 1979. Insurance Reform: Consumer Action in the Progressive Era. Ames: Iowa State University Press.

Hansmann, Henry. 1980. "The Role of Nonprofit Enterprise," 89 Yale Law Journal 835-901.

- 1984. Exclusive Organizations," Working paper no. 2, Program on NonProfit Organizations, Institution for Social and Policy Studies, Yale University.

Heflebower, Richard. 1980. Cooperatives and Mutuals in the Market System. Madison: University of Wisconsin Press.

Hetherington, John A. C. 1969. "Fact v. Fiction: Who Owns Mutual Insurance Companies," 1969 Wisconsin Law Review 1068-1103.

Houston, David, and Richard Simon. 1970. "Economies of Scale in Financial Institutions: A Study in Life Insurance," 38 Econometrica 856-64.

Huebner, S. S., and Kenneth Black. 1957. Property Insurance. New York: Appleton-Century-Crofts.

Josephson, Halsey. 1971. Life Insurance and the Public Interest. New York: Crow Publishers.

Kimball, Spencer, and Herbert Denenberg. 1969. Insurance, Government, and Social Policy: Studies in Insurance Regulation. Homewood: Richard D. Irwin.

Knight, Charles. 1920. "The History of Life Insurance in the United States to 1870." Ph.D. dissertation, University of Pennsylvania. 
MacAvoy, Paul. 1977. Federal-State Regulation of the Pricing and Marketing of Insurance. Washington, D.C.: American Enterprise Institute for Public Policy Research.

Manufacturers Mutual Fire Insurance Company. 1935. Factory Mutuals 1835-1935. Providence: Livermore and Knight Company.

Mayers, David, and Clifford Smith. 1981. "Contractual Provisions, Organizational Structure, and Conflict Control in Insurance Markets," 54 Journal of Business 407-34.

McGill, Dan M. 1967. Life Insurance. Homewood: Richard D. Irwin.

Mehr, Robert, and Emerson Cammack. 1976. Principles of Insurance. Homewood: Richard D. Irwin.

Nelli, Humbert, and Robert Marshall. 1969. "The Private Insurance Business in the United States Economy." Research paper no. 48, Bureau of Business and Economic Research, School of Business Administration, Georgia State College.

Stalson, J. Owen [1942] 1969. Marketing Life Insurance: Its History in America. Homewood: Richard D. Irwin.

Weber, Nathan. 1982. "Introduction: Reversals and Continuities," in N. Weber, ed., Insurance Deregulation: Issues and Perspectives. New York: The Conference Board.

Williamson, Oliver. 1979. "Transaction-Cost Economics: The Governance of Contractual Relations," 22 Journal of Law and Economics 233-61.

. 1983. "Credible Commitments: Using Hostages to Promote Exchange," 73 American Economic Review 519-40. 
